\title{
STOSUNEK PRAWA I SPRAWIEDLIWOŚCI DO WSPÓŁPRACY NIEMIECKO-ROSYJSKIEJ
}

\begin{abstract}
Prawo i Sprawiedliwość zostało utworzone w 2001 roku jako podmiot polityczny, który powstał jako partia polityczna odwołująca się do tradycji solidarnościowych. Z kolei Niezależny Samorządny Związek Zawodowy „Solidarność” powstał w latach 80., aby Polska uzyskała niepodległość i uniezależniła się od Związku Socjalistycznych Republik Radzieckich.

Prawo i Sprawiedliwość podkreślało, że polityka zagraniczna partii (koncepcja, strategia) była związana z geopolitycznymi wyzwaniami przed Rzeczpospolitą Polską. Współpraca niemiecko-radziecka i jej konsekwencje miały negatywne następstwa dla Polski oraz Polaków. Wydarzenia II wojny światowej spowodowały antydemokratyczne zmiany w Polsce. Polska Rzeczpospolita Ludowa była państwem niedemokratycznym i PiS oceniało, że było to spowodowane współpracą niemiecko-radziecką w II wojnie światowej.

PiS podkreślało, że współpraca niemiecko-rosyjska była niebezpieczna dla Polski także po transformacji ustrojowej. Obawy Rzeczypospolitej Polskiej były związane z działaniami Niemiec w Unii Europejskiej oraz współpracą pomiędzy Niemcami a Rosją. Współpraca niemiecko-rosyjska miała także wymiar polityczny oraz ekonomiczny. Szczególnie negatywnie przyjęto współpracę gospodarczą pomiędzy Niemcami a Rosją w zakresie NordStream oraz NordStream 2, co stwarzało niebezpieczeństwo gospodarcze dla Polski.

Przeciwwagą dla silnych więzi politycznych pomiędzy Republiką Federalną Niemiec a Federację Rosyjską była współpraca podjęta przez decydentów politycznych Prawa i Sprawiedliwości w zakresie współpracy państw Europy Środkowej i Wschodniej. Polska miała się stać liderem państw Europy Środkowej i Wschodniej.
\end{abstract}

Słowa kluczowe: Prawo i Sprawiedliwość, współpraca niemiecko-rosyjska, zjawisko politycznej odpowiedzialności.

Stosunki Rzeczypospolitej Polskiej i Federacji Rosyjskiej miały bardzo istotny kontekst - współpracę niemiecko-rosyjską. Specyficzne relacje niemiecko-rosyjskie miały znaczący kontekst gospodarczy (gazociąg północny), ale także historyczny. Zacieśnienie współpracy między Federacją Rosyjską a Republiką Federalną Niemiec zawsze rodziło obawy społeczeństwa polskiego oraz polskich decydentów. W tym kontekście można było postawić pytanie - czy trudna przeszłość mogła być trwałą przeszkodą w budowaniu wzajemnych relacji ${ }^{2}$.

Jarosław Kaczyński, premier RP w latach 2006-2007, ocenił, że celem prowadzonej przez niego polityki zagranicznej w odniesieniu do Niemiec i Rosji pozostawała nieustanna troska o polski interes narodowy. W kontekście relacji z zachodnim sąsiadem RP

\footnotetext{
${ }^{1}$ Mgr Tomasz Wicha, UMCS w Lublinie; e-mail: tomasz.wicha@interia.pl.

Tomasz Wicha, MSc, UMCS in Lublin; e-mail: tomasz.wicha@interia.pl.

2 J.M. Piskorski, Polacy i Niemcy. Czy przeszłość musi być przeszkodą?, Poznań 2004, s. 45.
} 
Jarosław Kaczyński stwierdził, że nie do zaakceptowania były dla Polski nieporozumienia z Niemcami odnośnie do moralnej oraz prawnej odpowiedzialności za II wojnę światową. Ocenił tego typu prowokacje jako absurdalne ${ }^{3}$.

Rządy Kazimierza Marcinkiewicza oraz Jarosława Kaczyńskiego z nieufnością przyglądały się zacieśniającej się współpracy niemiecko-rosyjskiej. Do kwestii, które różniły Polskę i Niemcy był budżet Unii Europejskiej, gazociąg północny, a także Ziemie Zachodnie i Północne, co omawiano na pierwszym spotkaniu kanclerz Niemiec Angeli Merkel, w Warszawie w 2005 roku.

Merkel, kierując się niemieckim interesem narodowym, co zauważył premier Marcinkiewicz, dokonała ponownego zdefiniowania interesu narodowego, bowiem nie byłoby silnych Niemiec bez dominacji tego państwa w Unii Europejskiej. Niemcy, będąc najsilniejszym graczem w Unii Europejskiej, stały się partnerem dla Rosji, poza decydentami Rzeczypospolitej i państw nadbałtyckich. Rewizja niemieckiej polityki zagranicznej zaczęła się już od rządów Gerharda Schroedera, który, jak się później okazało, miał udziały w spółce odpowiedzialnej za budowę gazociągu NordStream. Niemcy zbliżyły się do Rosji, ochłodzono stosunki ze Stanami Zjednoczonymi, a także zmieniono kurs wobec Rzeczypospolitej. Nowy rozdział polityki niemieckiej uwidocznił się w kwestii budowy gazociągu na dnie Bałtyku oraz w rewizjonistycznych działań Eriki Steinbach.

Przy analizie stosunku Prawa i Sprawiedliwości do współpracy niemiecko-rosyjskiej należy przywołać wypowiedź Lecha Kaczyńskiego z 2005 roku, w której prezydent RP odnosił się do stwierdzenia Władimira Putina o upadku Związku Radzieckiego oraz współpracy Niemiec i Rosji. Kooperację bilateralną uznał za bardzo korzystną dla obu stron. Federacja Rosyjska pragnęła, zdaniem Lecha Kaczyńskiego, ocenić, jak bardzo Polska gotowa jest zaakceptować zepchnięcie na margines polityki międzynarodowej. Lata po uzyskaniu suwerenności, w ocenie Lecha Kaczyńskiego, sprzyjały poczuciu, które mogło towarzyszyć decydentom rosyjskim, że Rzeczpospolita nie przeszkadzała Federacji Rosyjskiej w realizowaniu jej interesów na każdym z poziomów. Lech Kaczyński odniósł się także do zachowywania wstrzemięźliwości we wzajemnych kontaktach i ocenił, że według szerokiego gremium polityków na polskiej scenie politycznej nie ma równowagi między tym, co wolno Rosjanom, a czego mogli ewentualnie dopuścić się Polacy. Tego rodzaju polityka prowadziła do asymetrii w bilateralnych stosunkach oraz nierównowagi w ocenie działań obydwu państw na arenie międzynarodowej. Należało, w ocenie prezydenta Lecha Kaczyńskiego, w trybie pilnym zmienić politykę uzależnienia wobec surowców naturalnych pochodzących z Rosji, ponieważ taki stan prowadził do uwikłania w politykę zależności wobec wschodniego sąsiada Rzeczypospolitej ${ }^{4}$.

W kwestii budowy gazociągu NordStream powstało kilka propozycji, niekiedy się wykluczających. Początkowym pomysłem rządu Prawa i Sprawiedliwości była ,europeizacja” gazociągu północnego, który miał być własnością Unii Europejskiej lub poszczególnych państw. Gazprom miałby wówczas $25 \%$ udziałów. Zabiegano o kompromis, mając na względzie nie tylko charakter gospodarczy przedsięwzięcia, ale także możliwości jego wykorzystania w celach militarnych, obserwacyjnych czy wreszcie podsłuchowych.

${ }^{3}$ Strona internetowa PiS, http://www.pis.org.pl, ,Wstrzymujemy się od krytyki PO [rozmawiała Ewa Milewicz z Jarosławem Kaczyńskim]”, „Gazeta Wyborcza”, 25 października 2005 r., nr 249.

${ }^{4}$ Strona internetowa PiS, http://www.pis.org.pl, ,Wystawimy rachunek za krzywdy [rozmowa Jarosława Kurskiego z Lechem Kaczyńskim]”, „Gazeta Wyborcza” z 11 marca 2005 r., nr 113, inf. z 24 maja 2015 r. 
W gremiach partyjnych PiS pojawiła się rozbieżność wobec projektu. „Rzeczpospolita” opisała projekt, którego otoczenie Marcinkiewicza nie konsultowało z prezydentem Lechem Kaczyńskim ani z prezesem partii Jarosławem Kaczyńskim, co zakończyło się dymisją doradcy premiera Marcinkiewicza do spraw zagranicznych Ryszarda Schnepfa. Piotr Naimski, pełnomocnik rządu do spraw energetycznych zdecydowanie odradzał jakiekolwiek ustępstwa wobec projektu. Przedstawianie pozytywnych propozycji oceniano kontrskutecznie. Zjawisko polityki energetycznej stało się zatem bardziej symboliczne niż realne.

Relacje polsko-rosyjskie rozpatrywano zatem w kontekście relacji Berlin-Moskwa ze względu na surowce energetyczne. Kazimierz Marcinkiewicz, premier RP w latach 2005-2006 stwierdził na początku swego urzędowania, że Polska dysponowała wystarczającą ilością gazu ziemnego i nie było potrzeby budowania żadnej odnogi do już istniejących tras przesyłowych. Koniecznością jednak okazała się dywersyfikacja źródeł dostaw gazu ziemnego oraz ropy naftowej do Polski. Kwestia gazociągu bałtyckiego nie była dla Polski sprawą łatwą, stanowiła znaczącą trudność i w formule przedstawionej już w roku 2005 była dla rządu RP nie do zaakceptowania. Kazimierz Marcinkiewicz zaznaczył, że do wykonania pozostała druga nitka gazociągu jamalskiego, którą ocenił jako znacznie mniej kosztowną oraz szybszą w obsłudze. Rząd premiera Kazimierza Marcinkiewicza uważał, że druga nitka gazociągu jamalskiego była znacznie tańsza i szybsza. Nie było tym samym powodów, aby wstrzymywać ten projekt. Namawiano partnerów, w tym także reprezentantów Federacji Rosyjskiej do powrotu do projektu drugiej nitki gazociągu jamalskiego oraz porzucenia budowy gazociągu bałtyckiego ${ }^{5}$.

W kwestii dywersyfikacji dostaw ropy naftowej i gazu ziemnego do Polski wypowiadał się także Piotr Woźniak, minister gospodarki w rządach Prawa i Sprawiedliwości. Twierdził, że sytuacja geopolityczna Polski zmieniła się od 2004 roku wraz z wejściem do Unii Europejskiej, którą ocenić można jako poważną dźwignię w relacjach z Federacją Rosyjską. Zadaniem polityków Prawa i Sprawiedliwości było posłużenie się wszelkimi dostępnymi na forum Unii Europejskiej środkami, aby wspólnie wystąpić przeciw budowie gazociągu północnego. Piotr Woźniak przypomniał, że rynek gazu ziemnego w Europie pozostawał rynkiem dostawcy, $\mathrm{z}$ jednym dominujacym eksporterem. Taka sytuacja powodowała zawirowania na rynku surowców w Europie. Monopol rodził złe praktyki i rządy Prawa i Sprawiedliwości wyraźnie się przeciwstawiały monopolowi Gazpromu na rynku Unii Europejskiej, a faktycznie budowie gazociągu północnego, który łączył Rosję z Niemcami przy pominięciu Polski ${ }^{6}$.

Piotr Woźniak ocenił, że Rosjanie w 2003 roku do rządowej strategii energetycznej wpisali obowiązek wspierania przez sektor gazowy politycznych interesów Federacji Rosyjskiej w Europie. Minister gospodarki w rządzie PiS ocenił tego typu zjawisko jako nowe w stosunkach międzynarodowych i wskazał konieczność odniesienia się do tej kwestii w praktyce. Teza, która zawężała politykę surowcową do stwierdzenia, że strona rosyjska miała surowce, Polska ich potrzebowała a Rosjanie otrzymali za nie gratyfikację, była błędna. Decydentom Federacji Rosyjskiej nie chodziło bowiem o finanse. Kwestia opłaty za gaz ziemny pozostawiała jednak wiele nieścisłości, bowiem strona rosyjska mogła dyk-

${ }^{5}$ Strona internetowa PiS, http://www.pis.org.pl, „Wywiad Krzysztofa Grzesiowskiego z premierem K. Marcinkiewiczem w »Sygnałach Dnia«”, 23 grudnia 2005 r., inf. z 2 czerwca 2015 r.

${ }^{6}$ Strona internetowa PiS, http://www.pis.org.pl, Wywiad Moniki Olejnik z ministrem gospodarki Piotrem Woźniakiem w »Radiu Zet«”, 3 stycznia 2006 r., inf. z 2 czerwca 2015 r. 
tować dowolne warunki sprzedaży surowca. Nie tylko Polska, ale także Ukraina, zostały zaliczone przez Piotra Woźniaka do państw, które mogły się stać bezpośrednimi ofiarami gazowego monopolu Rosji w Europie. Jednocześnie trzeba było pamiętać, że Rosja dyktowała wysokie ceny surowców oraz determinowała rynek sprzedawców, zatem stawiała warunki. W Unii Europejskiej nie było mechanizmu zapewniającego bezpieczeństwo energetyczne, każde z państw osobno starało się zapewniać sobie bezpieczeństwo w tym aspekcie. Żaden awaryjny sposób, aby wyjść z ewentualnej kryzysowej sytuacji nie został wypracowany we Wspólnocie. Polska pozostawała więc narażona na odcięcie najważniejszych dla gospodarki, a także dla obywateli dostaw najważniejszych surowców. Była więc narażona na wojny gazowe w krajach sąsiednich oraz na złą wolę, którą mógł wykazać dostawca surowca ${ }^{7}$.

Kwestia bezpieczeństwa energetycznego była zadaniem nie tylko dla rządów PiS, ale pozostała aktualna także po zmianie władzy w 2007 roku. Wybory wówczas wygrała Platforma Obywatelska RP, która podpisała umowę ze stroną rosyjską na wieloletnie dostawy ropy i gazu ziemnego. Mariusz Błaszczak ocenił, że państwo polskie zawarło skrajnie niekorzystną umowę z Rosją na długoletnie dostawy gazu do Polski. W kontekście niemiecko-rosyjskiej współpracy może mieć to strategiczne znaczenie dla bezpieczeństwa państwa ${ }^{8}$.

W kwestii bezpieczeństwa energetycznego wypowiedział się także Zbigniew Wassermann, minister-koordynator ds. służb specjalnych w rządzie PiS. Wassermann ocenił, że był to priorytet dla rządów PiS. Federacja Rosyjska, w ocenie ministra, ponad Polską, prowadziła rozgrywki polityczne, które miały wzmocnić jej pozycję w regionie, kosztem Polski. Zmonopolizowane dostawy ropy naftowej i gazu ziemnego stały się punktem spornym w relacjach polsko-rosyjskich, bowiem przykłady działań rosyjskich na Ukrainie, w Gruzji oraz działalność na Białorusi pozwalały przypuszczać, że Rosja gotowa była posłużyć się wszelkimi metodami, aby doprowadzić do spolegliwości państw Europy Środkowej i Wschodniej. Ceną bowiem spokoju i bezpieczeństwa energetycznego stała się zgoda na działania podejmowane przez Federację Rosyjską na arenie międzynarodowej oraz w regionie. Jedną z metod, którą obrała Rosja, było zadłużanie się państw w ,rosyjskim portfelu". Wówczas rurociągi oraz gazociągi były przejmowane przez stronę rosyjską, co prowadziło do uzależnienia danego państwa od przesyłu surowców. Za rządów PiS, w ocenie ministra, zaczął działać kontrwywiad, co umożliwiło skuteczniejsze działania dyplomacji oraz przysparzało argumentów wobec możliwości weta w rozmowach Unia Europejska Rosja9.

Współpracę niemiecko-rosyjską opiniowano także przed szczytem Unia Europejska Rosja w Samarze. Paweł Kowal ocenił wówczas, że sąsiedztwo (z Rosją, ale i z Niemcami) generowało zawsze sytuację, w której znaleźć można było kwestie złe, trudne, ale także takie, które łączyły i stanowiły spoiwo. Wyróżnić można było zjawiska łatwe, ale także takie, które są trudne emocjonalnie. Globalne spojrzenie na stosunki polsko-rosyjskie, a szerzej stosunki Unii Europejskiej z Rosją pozwalało zrozumieć, że polityka zagraniczna

\footnotetext{
${ }^{7}$ Strona internetowa PiS, http://www.pis.org.pl, ,Rozmowa z Piotrem Woźniakiem na łamach »Rzeczypospolitej«", 7 maja 2007 r., inf. z 2 czerwca 2015 r.

${ }^{8}$ Strona internetowa Sejmu RP, http://orka2.sejm.gov.pl; „Przemówienie Mariusza Błaszczaka, Informacja ministra spraw zagranicznych o założeniach polskiej polityki zagranicznej $w 2011$ roku, 16 marca 2011 r.”, inf. 23 czerwca 2015 r.

9 Strona internetowa PiS, http://www.pis.org.pl, ,Wywiad ze Zbigniewem Wassermannem dla dzieńnika.pl, 4 grudnia 2006 r.”, inf. z 21 maja 2015 r.
} 
składa się z poszczególnych kwestii, których rozwiązanie determinuje powodzenie bądź nie danej polityki. Rosja próbowała obniżyć status Polski w Unii Europejskiej. Nikt rozumny, zdaniem Kowala, nie odrzuciłby oferty Rosji do współpracy, w kontekście gospodarczym i energetycznym. Tego typu zgoda nie mogła się jednak odbyć kosztem innych państw członkowskich Unii Europejskiej ${ }^{10}$.

Kwestia bezpieczeństwa energetycznego w kontekście zacieśnionej współpracy niemiecko-rosyjskiej pozostała aktualna za rządów Donalda Tuska nie tylko w kontekście bezpieczeństwa energetycznego. Anna Fotyga wyraziła w tej kwestii swe zaniepokojenie. Specyficzna bowiem była, zdaniem minister Fotygi, ingerencja Komisji Europejskiej w umowę gazową, którą na niekorzystnych warunkach wynegocjował rząd RP premiera Donalda Tuska. Zaproponowana umowa gazowa może uniemożliwić Polsce realną dywersyfikację dostaw surowców naturalnych oraz poszukiwanie alternatywnych źródeł energii. Te oceny pozostały szczególnie istotne w odniesieniu do skutecznego wykorzystania energii odnawialnej oraz eksploatacji gazu łupkowego. Minister Anna Fotyga stwierdziła także, że zmasowana krytyka opozycji zmusiła rząd do aktywności w kwestii bezpieczeństwa energetycznego Polski ${ }^{11}$.

W ocenie prezydenta RP Lecha Kaczyńskiego Polsce zależało na dobrych stosunkach z Federacją Rosyjską oraz Republiką Federalną Niemiec. Uważał on, że znajomość historii prowadzi do wniosku, że realizacja planów w polityce zagranicznej, które nie uwzględniały interesów Rzeczypospolitej Polski wywoływała obawy w kraju oraz na obszarze Europy Środkowej i Wschodniej ${ }^{12}$.

Przełomowym punktem w strategii bezpieczeństwa realizowanej przez Prawo i Sprawiedliwość oraz prezydenta RP Lecha Kaczyńskiego był szczyt energetyczny w Krakowie. Lech Kaczyński powiedział Marii Przełomiec, że szczyt energetyczny w Krakowie przyniósł deklarację, na podstawie której powołano wspólną grupę roboczą oraz spółkę komercyjną. Spotkanie stało się dowodem na zbliżenie państw niekiedy dość odległych geograficznie. Ocenić można, że działania na Wschodzie podjęte przez prezydenta Lecha Kaczyńskiego przyniosły rezultat. Stosunki polsko-ukraińskie zawsze były dobre, natomiast z odległymi państwami jak Kazachstan i Turkmenistan Rzeczpospolita praktycznie nie utrzymywała kontaktów politycznych. Jednym z dowodów na niskie relacje było ulokowanie Ambasady Polski w Kazachstanie zamiast w stolicy Astanie w oddalonej o niemal dwa tysiące kilometrów Ałma-Acie. W Turkmenistanie Rzeczpospolita w ogóle nie miała ambasadora.

Polska zamierzała wybudować odcinek ropociągu Odessa-Brody (100 km do Adamowa) i do 2012 roku polski odcinek miał być gotowy. Prezydent Lech Kaczyński zapewniał, że nie było to antyrosyjskie przedsięwzięcie. Dodał, że dywersyfikacja, czyli pozyskiwanie nowych rynków zbytu, leży w interesie państw, które były eksporterami. Putin zareagował na szczyt w Krakowie w charakterystyczny dla siebie sposób wizytami w Kazachstanie i Turkmenistanie. Lech Kaczyński stwierdził, że Rosjanie przestali mieć monopol produkcyjny, natomiast Azerbejdżan, Kazachstan i Turkmenistan dysponują zasobami

\footnotetext{
${ }^{10}$ Strona internetowa PiS, http://www.pis.org.pl, „Rozmowa z Pawłem Kowalem w »Sygnałach dnia «", 17 maja 2007, inf. z 21 maja 2015 r.

${ }^{11}$ Strona internetowa PiS, http://www.pis.org.pl, M. Bober, ,Rząd przekształca Polskę w kolonię [rozmowa z Anną Fotygą]”, ,,Rzeczpospolita” z 16-17 października 2010 r., inf. z 21 maja 2015 r.

12 Archiwum autora, Depesza PAP, ,Lech Kaczyński za poprawą stosunków z Rosją, lecz nie kosztem Polski”, 31 października 2005 r.
} 
tylko nieznacznie mniejszymi od rosyjskich. Lech Kaczyński, kontynuując wywód odnośnie do dywersyfikacji stwierdził, że państwo, które nie ma monopolu produkcyjnego nie może mieć długoterminowo także monopolu przesyłowego. Zadaniem Polski pozostało przekonanie państw członkowskich Unii Europejskiej do projektu energetycznego. Na pytanie redaktor Przełomiec - czy Polska nie jest zbyt słaba na tego typu grę z Rosją, Lech Kaczyński odpowiedział, że była to jedynie gra o charakterze regionalnym, do której Polska miała pełne prawo. Rosjanie wiedzieli, że Polska nie jest poważnym konkurentem dla Federacji Rosyjskiej, natomiast Unia Europejska pozostawała dla Rosji poważnym i znaczącym partnerem do rozmów ${ }^{13}$.

W opinii Anny Fotygi, minister spraw zagranicznych w rządach Marcinkiewicza oraz Kaczyńskiego, problem relacji polsko-rosyjskich był nie tylko kwestią relacji bilateralnych, ale także na szerszym poziomie Unia Europejska - Rosja. Kwestią problematyczną pozostało, że partnerom z Unii Europejskiej zależało na porozumieniu z Federacją Rosyjską za wszelką cenę. Takie nastawieni oznaczać miało szerokie ustępstwa Polski. Polska, w ocenie minister Fotygi, zawarła dżentelmeńską umowę z partnerami z Unii Europejskiej w kontekście relacji z Federacją Rosyjską. Bruksela miała wywrzeć presję na Moskwę w kwestiach gospodarczych (sektor energetyczny). Po stronie polskiej umowa zawężała się do enuncjacji w sprawie zniesienia weta w negocjacjach Unia Europejska - Rosja ${ }^{14}$. Jedynie strona polska wywiązała się z opisanej przez minister Fotygę dżentelmeńskiej umowy.

\section{LITERATURA}

1. Piskorski J.M., Polacy i Niemcy. Czy przeszłość musi być przeszkodą?, Poznań 2004.

2. Archiwum autora, Depesza PAP, „Lech Kaczyński za poprawą stosunków z Rosją, lecz nie kosztem Polski”, 31 października 2005 r.

\section{NETOGRAFIA}

1. Strona internetowa PiS, http://www.pis.org.pl, „Wstrzymujemy się od krytyki PO [rozmawiała Ewa Milewicz z Jarosławem Kaczyńskim]”, „Gazeta Wyborcza”, 25 października 2005 r., nr 249.

2. Strona internetowa PiS, http://www.pis.org.pl, ,Wystawimy rachunek za krzywdy [rozmowa Jarosława Kurskiego z Lechem Kaczyńskim]”, „Gazeta Wyborcza” z 11 marca 2005 r., nr 113, inf. z 24 maja 2015 r.

3. Strona internetowa PiS, http://www.pis.org.pl, ,Wywiad Krzysztofa Grzesiowskiego z premierem K. Marcinkiewiczem w »Sygnałach Dnia«", 23 grudnia 2005 r., inf. z 2 czerwca 2015 r.

4. Strona internetowa PiS, http://www.pis.org.pl, Wywiad Moniki Olejnik z ministrem gospodarki Piotrem Woźniakiem w »Radiu Zet «”, 3 stycznia 2006 r., inf. z 2 czerwca 2015 r.

5. Strona internetowa PiS, http://www.pis.org.pl, „,Rozmowa z Piotrem Woźniakiem na łamach »Rzeczypospolitej«", 7 maja 2007 r., inf. z 2 czerwca 2015 r.

\footnotetext{
${ }^{13}$ Strona internetowa PiS, http://www.pis.org.pl, „Rozmowa z Lechem Kaczyńskim na łamach »Dziennika«", 14 maja 2007 r., inf. z 25 maja 2015 r..

${ }^{14}$ Strona internetowa PiS, http://www.pis.org.pl, „Rozmowa z Anną Fotygą na łamach »Rzeczypospolitej«", 15 maja 2007 r., inf. z 25 maja 2015 r..
} 
6. Strona internetowa Sejmu RP, http://orka2.sejm.gov.pl; „Przemówienie Mariusza Błaszczaka, Informacja ministra spraw zagranicznych o zatożeniach polskiej polityki zagranicznej w 2011 roku, 16 marca 2011 r.”, inf. 23 czerwca 2015 r.

7. Strona internetowa PiS, http://www.pis.org.pl, „Wywiad ze Zbigniewem Wassermannem dla dziennika.pl, 4 grudnia 2006 r.”, inf. z 21 maja 2015 r.

8. Strona internetowa PiS, http://www.pis.org.pl, ,,Rozmowa z Pawłem Kowalem w »Sygnałach dnia«", 17 maja 2007, inf. z 21 maja 2015 r.

9. Strona internetowa PiS, http://www.pis.org.pl, M. Bober, „Rząd przekształca Polskę w kolonię [rozmowa z Anną Fotygą]”, „Rzeczpospolita” z 16-17 października 2010 r., inf. z 21 maja 2015 r.

10. Strona internetowa PiS, http://www.pis.org.pl, „Rozmowa z Lechem Kaczyńskim na łamach »Dziennika«", 14 maja 2007 r., inf. z 25 maja 2015 r.

11. Strona internetowa PiS, http://www.pis.org.pl, „,Rozmowa z Anną Fotygą na łamach »Rzeczypospolitej«", 15 maja 2007 r., inf. z 25 maja 2015 r.

\section{THE ATTITUDE OF LAW AND JUSTICE PARTY TOWARDS THE COOPERATION OF GERMANY AND RUSSIA}

Law and Justice party was established in 2001 and the decidents of the party expressed the positive approach towards the heritage of the movement of the Solidarity from 1980s. The movement of Solidarity was made to regain democracy in Poland and gain independence from the Soviet Union.

Many of the actions by Law and Justice party were done due to the geopolitical challenges of the Republic of Poland whereas there was the strong fear of the cooperation between the Russian Federation and Germany. It was the reference to the bad implications of the War War II as it caused the limitation of democracy of Poland and lack of independence.

Law and Justice claimed the anxiety concerning the strong cooperation between Germany and Russia was dangerous for the Republic of Poland. The cooperation of Germany and Russia has a strong and important context- economic. Apart from the economic context (NordStream gas pipeline) one may mention there was the historical fear of the cooperation between two empires as it lead to World War II and the outcomes of WWII were tragical for Poland as well. One of the core aspects of the foreign policy of Law and Justice party was the care for the Polish reason of state and the party was against the marginalisation of the Republic of Poland.

Keywords: Law and Justice party, German-Russian cooperation, the issue of political responsibility.

DOI: $10.7862 /$ rz.2018.hss.62

Przestano do redakcji: wrzesień $2016 r$.

Przyjęto do druku: wrzesień 2018 r. 
